\title{
CRITICAL DISCOURSE ANALYSIS OF THE SHORT FICTION "MAGIC" BASED ON NORMAN FAIRCLOUGH'S APPROACH
}

\author{
Patricia Natasya Rhea Sudarna ${ }^{1}$, Christina Atika Yulina ${ }^{2}$ \\ patriciarheal@gmail.com, \\ christinatikaa@gmail.com
}

English Language Studies, Universitas Sanata Dharma

\begin{abstract}
In the discussion about social injustice, inequality becomes a core issue. It is proven by inequality themed short stories which are still relevant nowadays although they were written decades ago. In this paper we analyse the 1928's short story Magic written by Katherine Anne Porter under Fairclough's (1922) critical discourse analysis. It aims at finding social wrongespecially inequality issues in the short story and finding possible ways to solve the social wrong. The analysis will be done in the framework of Fairclough's critical discourse methods which divides the discourse into three dimensions, i.e. linguistic description of the language text, interpretation of the relationship between the discursive processes and the text, and explanation of the relationship between the discursive processes and social processes (Fairclough, 1995). To describe the linguistic aspect of the text, appraisal theory is used as the approach to support the process of analyzing the linguistic elements that create the discourse. Thus, the analysis will link the linguistic and social contexts of the discourse. The results show that there are some social wrongs happen in the story. It is also shown through judgement, affect, and appreciation.
\end{abstract}

Keywords: Magic, Fairclough, appraisal theory

\section{INTRODUCTION}

In the discussion about social injustice, inequality becomes a core issue. This issue is declared by society in many ways. Most of them are aimed to raise people's awareness towards inequality that is happening really close around us. It also encourages the audience to make movement. In the field of literature, there are numbers of literary works that carries inequality as its main theme. It is proven by numerous books, poems, and stories raising inequalities as its theme. Many of them were written decades ago, but because the issues is still exist, they are still relevant up to now.

The term inequality is used not only to refer gender injustice or women's rights, but also to describe the differences between race, ethnic, and social class. In inequality, a character will be considered to be in the lower position than the other. Then, the other characters will be easily dominate or manage the lower class.

A short fiction "Magic" by Katherine Anne Porter becomes one of the most well-known story that shows inequality as its main theme. It is an interesting object to be analyzed since it shows the realities of life that are closely related to injustice and social power at that time. 
Porter's fictions are usually talked about women who are fail to achieve the identities that they seek, instead, they ironically become victims of their own or others' ideas of what they ought to be.

The short fiction is considered as a 'framed story' which means there is a story inside a story. It is written that there was a Creole maid who worked for a lady named Madame Blanchard. One day, when the Creole maid combed Madame Blanchard's hair, she told Madame Blanchard a short story about a harlot named Ninette who worked at brothel run by a cruel madam who cheated her employees out of money and beat them if they objected. Ninette's life was not happy at all. She experienced many injustice, both from his mistress, as well as from her surrounding. She could not hold the suffering anymore. She made up her mind to run away from the place of prostitution. Unfortunately, her cruel madam could easily make her come back to brothel through the black magic that she gave to Ninette.

In the literature, there are several research that analyze Porter's short fiction. However, only few of them are focusing on "Magic". A master's thesis that have been done by Smith (1959) tries to analyze symbolism in Potter's short stories. There are three stories that were analyzed; "Pale Horse, Pale Rider", "The Flowering Judas", and "The Leaning Tower". The purpose of the research is to show how and to what extend the symbolism is used in the stories. Another thesis, written by Winters (1993), is aimed to reveal the relationships between women in Potter's short fictions. The research examines the reasons why Porter felt as she did toward the idea of feminism and how these feelings affected both her portrayal of relationship between men and women, and her portrayal of relationships between women. The results of this study show that. The writers only find limited studies which analyze Porter's short fiction specifically about "Magic".

On another hand, implementation of CDA Framework to analyze short fiction is quite common in the literature. A paper written by Rashidi, et at. (2014) applies CDA to investigate the representation of men and women in Bozorg Alavi's short stories. They would like to find how different statuses of men and women are reflected in their languages. To analyse the data, they use Hodge and Kress's syntagmatic models. The results of this study show that men have higher status than women do in these stories. Ma'yuuf (2020) uses CDA Framework to explore discrimination in English children short stories. The paper aims at uncovering the embedded ideology through the relations between textual analysis and socio-context. The finding of the study indicates that children are bitterly subjected to discrimination of diverse type; gender, race, and colour. Another analysis is written by Zinnivand (2020) which analyzes the short story "Through Alkhlas" using Norman Fairclough's approach and model for the concepts of power, ideology, and inequality in the context of offers. The analysis suggest that the story shows deep challenges; challenge the traditional opposition between men and women, modern women, one steeped in ignorance and false beliefs and traditional society reproduces the dominant discourse.

Among those research, it can be concluded that CDA Framework is used to know the ideology behind the constructed social wrongs that exist in the stories through its linguistics features. In this paper, CDA Framework is addressed to answer a research question: to what extend the social wrongs experienced by the oppressed character represented in the short fiction "Magic" by Katherine Anne Porter? This research is aimed to address the existing gaps by analyzing injustice and inequality in the short fiction.

In this paper, the short fiction Magic is analyzed using Fairclough's critical discourse analysis. Fairclough's critical discourse analysis connects the social aspects and linguistic 
aspects that exist in the discourse. He divides critical discourse analysis into three dimensions, namely linguistic description of the language text, interpretation of the relationship between the discursive processes and the text, and explanation of the relationship between the discursive processes and social processes. Therefore, to analyse the linguistic aspect, which is belong to the first dimension, the writer also uses appraisal theory as a complement to the dimensions of textual analysis. Furthermore, the linguistic theory will support the Fairclough's social theory.

Fairclough offers four 'step' of critical discourse analysis. First, focus upon a social wrong, in its semiotic aspects. Second, identify obstacles to addressing the social wrong. Third, consider whether the social order 'needs' the social wrong. Fourth, identify possible ways past the obstacles. On the other hand, appraisal theory divides sentences into three, namely affect, judgement, and appreciation. In appraisal theory, it is believed that grammar is a resource of meaning. This paper aims to reveal the social wrong experienced by the characters in "Magic". The linguistic theory is expected to enable the writer to see how the writer describes certain character and relationship between them in the story through the words employed.

Therefore, it can be concluded that Fairclough's theory focuses on solving the social problems that occur in the discourse. While the linguistic theory will put certain concepts as the evidence. Through linguistic theory, the writer will give evidence on how language has a certain power to create the social wrong-oppressing or dominating people. The use of those theory is aimed to answer the stated research question.

\section{THEORETICAL FRAMEWORK}

\section{Critical Discourse Analysis}

Critical discourse analysis (CDA) is a qualitative analytical approach for critically describing, interpreting, and explaining the ways in which discourses construct, maintain, and legitimize social inequalities. Furthermore, Fairclough (1993) defines critical discourse analysis as a type of discourse analytical research that primarily studies the way social power abuse, dominance and inequality are enacted, rep roduced and resisted by text and talk in the social and political context; with such dissident expose and ultimately to resist social inequality. Critical Discourse Analyis (CDA) is aimed to expose what was wrong in society: injustice, inequality, restrictions on freedom or discrimination so that an unfair or oppressive situation can be changed. Hence, those two theories sees language as purposeful, regardless of whether discursive choices are conscious or unconscious. The purpose of conducting critical discourse analysis is mainly to seek the ideology behind the text; what is the text wants to convey, or what is the writer purpose of writing the discourse.

\section{Norman Fairclough's Approach}

Fairclough's theory of critical discourse analysis assumes that there is a dialectical relationship between language and other elements of social life. The theory focuses on both specific text (linguistic analysis) and orders of discourse (interdiscursive analysis) (Fairclough, 2003). This theory wants to show that text analysis and social theory can help each other to present rich description to produce critical discourse analysis. Thus, applying Fairclough's approach means that the researcher presents both the linguistics description of the text and the social theory. Golzadeh (2007) in Rashidi (2014) notes that the linguistic analysis in critical discourse aims at discovering the process of articulation and perceptions, which enables the analysts to observe the work of ideology in the language and introduce it to others. 
Furthermore, the typical characteristic of CDA by Fairclough is that the subject analyzed covers three main things which cannot be separated one another. They are; language structure, diction, and meaning. Each of them are analyzed separately but supporting one another. The language structure will usually be analyzed first because the sentences with certain structure gives certain message. Further, the diction used in the discourse also gives special sense that might be used as prior ideology. Moreover, meaning of the discourse is also an important thing in the analysis according to Fairclough. However, for analyzing the language structure, this research applies the appraisal theory to support the findings of social problem which were found in the short story "Magic". Appraisal theory divides sentences into three, namely affect, judgement, and appreciation. In appraisal theory, it is believed that grammar is a resource of meaning. This paper aims to reveal the social wrong experienced by the characters in "Magic". The linguistic theory is expected to enable the writer to see how the writer describes certain character and relationship between them in the story through the words employed.

On the other hand, related to the social analysis, Fairclough offers four 'step' of critical discourse analysis. The steps of applying Fairclough theory to conduct critical discourse analysis are; First, focus upon a social wrong, in its semiotic aspects. Second, identify obstacles to addressing the social wrong. Third, consider whether the social order 'needs' the social wrong. Fourth, identify possible ways past the obstacles. On the other hand, appraisal theory divides sentences into three, namely affect, judgement, and appreciation. In appraisal theory, it is believed that grammar is a resource of meaning. This paper aims to reveal the social wrong experienced by the characters in "Magic". The linguistic theory is expected to enable the writer to see how the writer describes certain character and relationship between them in the story through the words employed.

\section{Appraisal Theory}

Appraisal theory is used as the approach to support the process of analyzing the linguistic elements that create the discourse. Appraisal framework, developed by Martin and White (2005), provides for analyses of those meanings by which texts convey positive or negative assessments, specifically literature divides attitudinal meanings into the following three broad subtypes: affect (positive/negative assessment presented as emotional reactions), judgment (positive/negative assessments of human behavior and character by reference to ethics/morality and other systems of conventionalized or institutionalized norms), and appreciation (assessments of objects, artifacts, texts, states of affairs, and processes in terms of how they are assigned value socially). The concept of attitude moves beyond the writer's emotion to deal more comprehensively with feelings including affect, judgment and appreciation (Martin \& White, 2005). Using the appraisal theory, the researcher tries to outline a framework to map the feelings as they are construed in the articles, referring to the system of meanings as attitude that involves three semantic regions of emotion (as seen as affects), ethics (as seen as judgments) and aesthetic (as seen as appreciation).

\section{METHOD}

This study used document analysis as the method. It analyzed the short story "Magic" by Katherine Anne Porter. Therefore, the main data were gathered from the sentences in the short story. Then, the data were analyzed using Fairclough's social theory which divided discourse analysis into three dimensions, they are; linguistic description of the language text, 
interpretation of the relationship between the discursive processes and the text, and explanation of the relationship between the discursive processes and social processes.

Moreover, to do the critical discourse analysis, the writer used the four steps of Norman Fairclough's Critical Discourse Analysis method. The method is used to find the social wrong in the short story. The first step is looking for the social wrong that is exist in the story explicitly or implicitly. The second one is identifying the obstacle to address the social wrong. In this step, the researcher finds out the possible obstacle to solve the social wrong. The third step is the researcher decides whether the social order needs the social wrong or not. And the last step is the researcher provides some solution related to the social wrong (Fairclough 2010, p. 235).

Textual analysis was also done to support the critical discourse analysis. On textual analysis, appraisal theory is used to support the findings of social problem which were found in the short story. Structurally, this critical discourse analysis was done by doing the steps suggested by Yoce (2005: 207) namely (1) choosing text to be analyzed; (2) determining the focalizer of the story; (3) determining the object of focalization or focalized object; (4) describing the language used in the text; (4) giving and interpretation of the types of ideology; (5) giving explanation about inequality.

\section{FINDINGS AND DISCUSSION}

\section{Appraisal Theory Analysis of Magic}

This paper analyses the social wrongs that might be happened in a short story Magic. Before finding the social process that might happen in the story, Fairclough's three dimension of critical discourse analysis allows us to do linguistics description of the text. In this part, this paper will present the results of the linguistic analysis done by the researcher as the first dimension in critical discourse analysis proposed by Fairclough. The percentage of appraisal theory analysis of Magic is presented in Table 1.

Table 1. Appraisal analysis

\begin{tabular}{|c|l|c|c|c|c|}
\hline \multirow{2}{*}{ No } & \multirow{2}{*}{ Attitude } & \multicolumn{2}{|c|}{ Positive } & \multicolumn{2}{c|}{ Negative } \\
\cline { 3 - 6 } & & Freq & \% & Freq & \% \\
\hline $\mathbf{1}$ & Affect & 11 & $61.1 \%$ & 14 & $63.6 \%$ \\
\hline $\mathbf{2}$ & Judgement & 4 & $22.2 \%$ & 6 & $27.3 \%$ \\
\hline $\mathbf{3}$ & Appreciation & 3 & $16.7 \%$ & 2 & $9.1 \%$ \\
\hline & TOTAL & $\mathbf{1 8}$ & $\mathbf{1 0 0 \%}$ & $\mathbf{2 2}$ & $\mathbf{1 0 0 \%}$ \\
\hline
\end{tabular}

From Table 1, it can be seen that the writer mostly uses affect to describe the feeling or event experienced by the characters. Below is a short discussion about the results of analyzing the short story using appraisal theory.

\section{Affect}

Table 1 shows that the most dominant type to describe the characters in the story is affect. From the total 35 clauses, there are 25 clauses (consist of 11 positive and 14 negative) that are categorized as affect. Affect is divided into three, namely affect as quality, process, and comment. Moreover, affect as quality is divided into describing participants, attributing participants, and manner of processes; and affect as process is divided into mental and behaviour. Below are the examples of effects to describe the events and characters.

... I am happy to be here with you and your family (affect as a process) 
The sentence above is an example of affect as a process of mental. The word happy represent the feeling of the participant toward the live that she lived at the moment. In the context is her life with 'you' and 'your family'.

... she looked very sick, the same clothes and all, but happy to be there. (affect as quality)

Excerpts above shows the use of affect as quality to attribute the participant. The sentence explains that the girl looks very happy to be there. The word happy represent the feeling of the girl.

\section{Judgement}

The second dominant type uses in the text is 'judgement'. From the total 35 clauses, it can be seen that 10 clauses (consist of 4 clauses positive, and 6 clauses negative) are judgment. Judgement is divided into two, namely judgement of esteem and judgement of sanction. Further, judgement of esteem and judgement of sanction clauses are broken down into smaller types, which are 'judgement of esteem normality', 'judgement of esteem capacity', 'judgement of esteem tenacity', 'judgement of sanction veracity', and 'judgement of sanction propriety'. Below are the examples of judgement.

...she could make men work for her too (judgement of esteem)

The sentence above is one of example of judgement of capacity. It shows that the participant has the power to make men work for her. She has the choice to make men work for her or not. esteem)

... but she had a very hard heart, she helped the madam in everything (judgement of

The sentence above contains a judgment of capacity. The noun hard heart displays the capability of the participant to do several things with her ability. The participant has power to do certain things.

\section{Appreciation}

The least dominant attitude found in the short story written by Katherine Anne Porter is 'appreciation'. From the total 35 clauses, there are 5 clauses (consist of 3 clauses positive, and 2 clauses negative) that are categorized as appreciation. Appreciation is divided into three types namely reaction, composition, and valuation. Moreover, reaction and composition are broken down into smaller types which are 'appreciation reaction impact', 'appreciation reaction quality', 'appreciation composition balance', and 'appreciation composition complexity'.

... there was a girl there in that house, a poor thing, thin, but well-liked by all the men (appreciation as reaction)

The sentence contains appreciation as reaction of quality. The sentence tries to evaluate the girl. It wants to explain that although the girl is thin and weak, she is liked by many men. It shows that she has a good quality. In term of her service or the others.

... but she had a very hard heart, she helped the madam in everything

The sentence above shows the existence of appreciation. The sentence tries to say that the participant has a good heart. She helps the madam in doing certain works. 


\section{Critical Discourse Analysis using the four steps of Fairclough's Method}

The data above is used to explain the relationship between the discursive processes and social processes. It is going to be used to complete the four steps of doing critical discourse analysis proposed by Fairclough in this following discussion.

\section{Identification of the Social Wrong}

The short story clearly talks about a harlot named Ninette who experienced injustice and violence both mentally and physically by her surroundings. Madame Blanchard becomes the main character who brings Ninette to her suffering. Other than that, if the story is analyzed deeper, there are also some events that represent injustice among the other parties involved in the story. Below are the social wrongs that can be found in the story:

\section{$\underline{\text { Racial inequity }}$}

In a short story "Magic", it is portrayed a Negro who always works as a maid. She wanted to do everything to support her life because it was difficult for a Negro to find a work at that time. The Negro maid is once a servant in a bordello owned by a Blanchard but then she employed in the house of Madame Blanchard. He has already experienced many ups and downs in her life. Injustice and violence become things that is close to her. From the maid's experience, it can be seen that the social class is dominated by white at the moment. Madame Blanchard representing the white aristocracy that oppresses the black serving class represented by the maid.

... I work always where there is work to be had, and so in this place I worked very hard all hours (Judgement of esteem)

The excerpt above tells about the Negro maid who is willing to do anything to support her life. Judgement of esteem - positive capacity is used to show that the maid has to work very hard because of the demand from her madame.

\section{Injustice among certain classes}

In running her business, the cruel madame did everything to make her get the benefit as much as she wants. She cheated her employees out of money and beat them if the objected. The violence was also happened to Ninette. When the spunky Ninette tried to leave the brothel, the madam kicked her brutally and threw her out in the street to survive on her own. The workers were treated like slaves who must obey and depend on the madame.

... she always hit people over the head with bottles, it was the way she fought. (judgement of esteem)

... and began to lift her knee and kick this girl most terribly in the stomach, and even in her most secret place

The sentences show the character of Madam who own the brothel. She always hit people using bottles. The sentences also explain that it is the way the Madam fights. Whenever she feels upset, she uses violence to express her anger. Ninette, as her popular harlot who gives her much money also treated like that.

... now you can get out, you are no good for me any more (judgement of esteem)

Her anger led to Ninette's expulsion from the brothel. The intention of kicking Ninette is to make her does not look good anymore. Injuries all over Ninette's body make no one interested with her. Moreover, the slavery done by the brothel madame was not only imprisoning Ninette physically but also pressing her spirit and passion in living her life. 
... there was a true hatred between her and the madam. (affect as quality)

Sentence above shows that Ninette is unhappy. She hates the Madam very much since she does not treat Ninette as a human being. She forces Ninette to work hard with less money. The Madam takes most of Ninette's money. She cheats on Ninette's check. The sentence below states that Ninette is the most popular harlot that she has. She is able to make money more than other harlots in the brothel. However, she does not treat her in a good manner.

... I make more money than anybody else in the house (judgement of esteem)

The story ends with an irony; Ninette's return to the cruel brothel. Ninette who tried to set her life free from slavery turned to face that she failed to get what she wants. She came back to the brothel, greeted with 'Welcome home, Ninette' by the people at the brothel. Her return caused ambiguity - was it through magic or through determinism of the situation?

There is a big possibility that Ninette's return was not only because of the magic done by the madame. Ninette who used to be brave in finding her happiness by escaping from the brothel turned out could not find any place to go. There was nowhere else for her to go, therefore, she decided to return to the Madam, where she would again be cheated, but where she was in demand by the customers. This cruel life left Ninette with no choice. She would always live in injustice.

... then in seven nights the girl came back and she looked very sick (affect as quality)

... the same clothes and all, but happy to be there. (affect as quality)

... and after that she lived there quietly (affect as quality)

The sentences above show that Ninette comes back to the brothel will a bad condition. It is assumed that she cannot support her own life outside the brothel. Her only choice is to stay in the brothel for the rest of her life.

\section{Patriarchal Ideology}

"Magic" also portrays the power of men at that moment. Men also play a role in the injustice experienced by Ninette and other harlots. In Madam's brothel, men have the power to support the horrible system in the brothel. The more their requests, the more Madam would be happy since it would increase her profit. However, these conditions made Ninette and other harlots must receive harsh treatment and coercion from Madam.

... after this the men who knew this girl kept saying, where is Ninette?

... they kept asking this in the next days

The excerpt shows that Ninette is wanted by most of men in the brothel. They always ask about Ninette. They want Ninette to serve them. This demand makes Madame wants Ninette to come back to the brothel. It is one of the proves that shows men's power, they have the power to control Ninette's life.

\section{... they always came back with the policemen or with another kind of man}

Moreover, the police character in the story was described as a bad party. In this story, the police - and also some of Madam's male friends have the power to determine the fate of Ninette and other harlots. If a harlot runs away, the men will leave them with two choices; the girls must come back with them or go to the jails.

\section{Identification of Obstacles to Solve the Social Wrong}

It is not easy to solve the social wrong in the short story "Magic". There are some obstacles that might inhibit us to solve the social wrong; racial inequity, injustice among certain 
classes, and patriarchal ideology. Most of the obstacles come from the social order itself. They unconsciously want the social wrong. For example, Ninette, a harlot who experienced many injustices in her life. We cannot easily help Ninette to be free from injustice in her life. It is because Ninette herself was 'intentionally' - even if she was forced to, make herself involved in the social wrong itself because she needs an environment that support her financially.

Other than that, other obstacles that might happen in solving injustice and inequity in the context of the short story is that; many people are afraid to become a minority in upholding justice. Being different in an any situation is a tough thing, especially in fighting something bad that has dominated and seems to be 'intentionally created'.

\section{The Social Order 'Needs' the Social Wrong}

In the short story "Magic", it is believed that the social wrongs that occur are something which are wanted by the circumstances themselves. The first is racial inequity and injustice among certain classes. Negro people at that time was considered to be someone with a low class and no education. The stigma was deliberately created so that the whites, at that time, had a controlled-class that could be enslaved and would be paid a low salary. This puts the Negro maid always be a maid wherever she works. Although she said to Madam Blanchard that there was French blood flowing in his body, the white still considered it a lower class because she is a Negro.

Then, the inequality experienced by Ninette is also something that is needed by the environment. Madam Blanchard is obsessed with getting lots of profit from Ninette. While the customers also need Ninette to serve them. Whereas Ninette herself turns out needed the social wrong to support her life. This is proven by Ninette's decision to return to the brothel.

Patriarchal ideology is also something that is intentionally made. Physically, men are stronger than women. It creates power relations between man and woman. This makes Ninette and other harlot in the story have no power when caught by the man. Moreover, these men have more power, such as the police character told in "Magic".

By looking at these aspects, it can be concluded that the social order supports the occurrence of social wrongs in the story. The social order needs the wrong social so that various parties can always get the benefit.

\section{The Possible Ways to Solve the Obstacles}

If we are referring to social orders that require social wrong, it seems like there is no way out to solve the social wrong. However, there are several ways that might be possible to fix the social wrong. First, it needs to be remembered that every job requires someone who is capable in carrying out the job description, so that any work is suitable for anyone who comes from any group and racial background. This kind of mindset can reduce stakeholder intentions in choosing workers based on their racial background.

Moreover, a possible way that might be done to solve injustice in the world of prostitution like experienced by Ninette is to create a community of workers that work as harlot like Ninette. The community is expected to work as a union that can later fight injustices that occur among their friends who has the same profession. By creating a large community, they will be stronger and braver in facing the injustices that occur in their brothel. 


\section{CONCLUSION}

In conclusion, the character that is oppressed in the short story 'Magic' is a harlot named Ninette. Fairclough's four steps of critical discourse analysis finds that the social wrong in the story are racial inequity, injustice among certain classes, and patriarchal ideology. However, there are some obstacles in solving the social wrong since the social wrongs are created because of the need of social order. The social intentionally create the social wrong so that it can give benefits to the parties involved. Moreover, the character that is seen as 'oppressed' - Ninette, also needs the social wrong to support her life.

However, there are some ways that can be done in order to solve the social wrong. First, to eliminate racial differences in each job/position, it is important to remember that what is needed in each position is the capability of the worker in doing the job description, not what race and class the worker is from. Second, the injustices experienced by harlots can be prevented and reduced by forming professional groups. The group is expected to support each other and defend injustice. Those social analysis is also supported by appraisal theory that gives evidences to the events and situations which are happened in the story. It is clearly shown through the existence of affect, judgement, and appreciation.

\section{ACKNOWLEDGMENT}

We would like to thank Rm. Haryatmoko, SJ., Dr. B.B. Dwijatmoko, M.A., and students of Critical Discourse Analysis class (ELS 2019) for their advice and encouragement throughout this project. May God always be with us.

\section{REFERENCES}

Al-Khattabee, S. A. H., (2020) Discourse analysis of short story 'The Man of the House'. College of Basic Education Researchers Journal, 16(3)

Darma, Yoce Aliah. (2009). Analisis Wacana Kritis. Bandung: Yrama Widya.

Fairclough, Norman. (1992). Discourse and Social Change. Cambridge: Polity Press.

Fairclough, Norman. (1995). Critical Discourse Analysis: The Critical Study of Language. London \& New York: Longman.

Fairclough, Norman. (2000). Critical Analysis of Media Discourse. In Paul Marris and Sue Thornham (peny.). Media Studies A.

Fairclough, Norman. (2001). Critical Discourse Analysis. Int. Adv. Eng. Technol. 7. 452-487.

Fairclough, Norman. (2003). Analysing discourse: Textual analysis for social research. London: Routledge.

Haryatmoko. (2017). Critical discourse analysis. Depok: Rajawali Pers.

Hosseini, A., \& Sattari, E. (2018). A Review Of Naguib Mahfouz's 'The Beggar' Based On Norman Fairclough's Critical Discourse Analysis. PEOPLE: International Journal of Social Sciences, 4(1), 525-541.

Johnstone, Barbara. (2007). Discourse Analysis 2nd Edition (Introducing Linguistics). Oxford: Wiley-Blackwell Publishers Ltd.

Kendenan, Esriaty S. \& Sumarlam. (2018). Gender ideology in seno gumira ajidarma's clara: A critical discourse analysis. Advances in social science, education and humanities research. Volume 280. 
Martin, J. R., \& White, P. R. R. (2005). The Language of Evaluation: The Appraisal Framework. Lecture Notes in Computer Science, 256.

Mayuuf, Hussain \& So'ad, Khudhair. (2020). A Critical discourse stylistic analysis of discrimination with supply chain practices in English children short stories. International Journal of Innovation, Creativity and Change I,10. 774.

Porter, Katherine Anne. (1928). The story of an hour. Retrieved from shortstoryproject.com/story/magic/

Rashidi, N., Khormaei, A., \& Zarei, M. (2014). The critical discourse analysis of the representation of women and men in Bozorg Alavi's short stories. Advances in Language and Literary Studies, 5(3). https://doi:10.7575/aiac.alls.v.5n.3p.126

Smith. Mary St. Peter. (1959). Symbolism in the Short Stories of Katherine Anne Porter (Master's Thesis). Loyola University Chicago: Chicago.

White, Peter R.R. (2015). The language of attitude, arguability, and interpersonal positioning: The appraisal website. http://www.languageofevaluation.info/appraisal/index.html. Retrieved on Dec 1, 2019.

Winters, Stacey L. (1993). Sister or Rival: Relationships Between Women in the Short FIction of Katherine Anne Porter (Master's Thesis). Oklahoma State University: Oklahoma.

Zinnivand, T., \& Soulati, S. (2020). Critical discourse analysis of the short story "Thrigh Alkhlas" based on Norman Fairclough's approach. The Quarterly Journal of Lesān-E Mobeen (Research in Arabic Literature). 11(38) 